\title{
Ysengrin no poço
}

Rodrigo Fernandes de SOUSA* Viviane Moraes de Caldas GOMES ${ }^{* *}$

É melhor que eu lhes conte uma história engraçada, já que eu bem sei que, na verdade, vocês não têm interesse em escutar um sermão ${ }^{1}$ ou uma vida de santo ${ }^{2}$. O que vocês querem é algo divertido. Façam então silêncio porque eu estou em boa forma e tenho mais de uma história que vale a pena ser ouvida. Muitas vezes me confundem com um louco, mas escutei na escola dizerem que a sabedoria também sai da boca do lunático. Pois bem, é inútil perder mais tempo para o que tenho a lhes dizer! Não vou mais tardar em contar uma das travessuras - apenas uma - de um mestre da malandragem. Trata-se de Renart, a raposa - não sou eu que vou lhes ensinar. Ninguém é capaz de fazê-lo exercer suas funções enquanto, ele mesmo, se põe a devorar todo o mundo. Desde sua infância ele seguiu o mau caminho. Por mais que a gente o conheça, acaba caindo em suas peças. Ele é cuidadoso, astuto e age em segredo. Mas, nesse mundo, nem mesmo o sábio está protegido da loucura.

Eis aqui então a desventura que lhe aconteceu. Um dia, totalmente pobre e torturado pela fome, ele estava em busca de comida. Entre pastos, matas e matagais, ele se vê miserável e furioso por não encontrar nada que possa comer no jantar: nem mesmo nada para colocar no buraco do dente. Retomando então o passo constante, ele chega à beira de um bosque onde pára, bocejando de fome, se espreguiçando de tempos em tempos, completamente magro, descarnado, e sem saber o que fazer: já que a fome reinava por todo o país. Suas tripas se perguntam o que estão fazendo suas patas e seus dentes. Torturado pela fome, ele não pode conter os gemidos de sofrimento e desespero. "Mas o que de bom esperar lá onde nada há mais para roubar?", se pergunta ele. Pensando assim, viaja um acre inteiro, sem cessar, seguindo uma trilha que leva a uma encruzilhada. Esticando o pescoço, ele percebe, dentro de um cercado próximo a um campo de aveia, uma abadia de monges de branco ${ }^{3}$ com uma granja vizinha, que ele decide eleger como alvo. Ela era solidamente construída com muros de uma

\footnotetext{
* Aluno do Programa de Pós-Graduação em Linguagem e Ensino (Pós-LE) da Unidade Acadêmica de Letras (UAL) da Universidade Federal de Campina Grande (UFCG). E-mail: rfernandesufcg@ gmail.com.

** Aluna do Programa de Pós-Graduação em Linguagem e Ensino (Pós-LE) da Unidade Acadêmica de Letras (UAL) da Universidade Federal de Campina Grande (UFCG). E-mail: vivianegomes@gmx.de.

${ }^{1}$ Discurso religioso e moral. (N. do A.)

${ }^{2}$ Durante a Idade Média, a Igreja apresentava a vida dos santos como modelos de conduta. (N. do A.)

${ }^{3}$ Monges cistercienses portam hábitos totalmente brancos (diferentemente dos beneditinos que sustentam hábitos negros). (N. do A.)
} 
pedra cinzenta muito dura - podem acreditar em mim - e cercada por um fosso com bordas difíceis de subir: impossível entrar em um lugar tão seguro para roubá-lo. Contudo, não faltavam mantimentos nele nem em quantidade nem em qualidade. Que granja atraente, que muitos ignoram até a existência. E justamente ela está cheia dos alimentos preferidos de Renart: galinhas e capões engordados na medida certa. Ele se dirige, então, a esse lado, avançando no meio do caminho, louco para passar logo ao ataque. Sequer faz questão de descansar antes de chegar à entrada dos capões. Ele só sossega mesmo quando enfim atinge a frente do fosso, pronto para se lançar sobre as galinhas e embolsar seu prêmio. Mas nada pode fazer por lá. Em vão ele contorna a granja apressado, já que não encontra nem escada de acesso, nem ponte, nem abertura. Era de se desesperar! Contudo, ao se agachar ao pé da porta, percebe que um pequeno alçapão entreaberto deixa uma passagem que lhe permite se infiltrar para o interior. Eis aqui o lugar ideal, onde, entretanto, sua localização não é segura, já que, se os monges perceberem o trote que ele quer lhes dar, lhe farão pagar caro, mantendo-o preso ali mesmo, tão malvados eles são. O que importa! Quem não arrisca, não petisca! Renart, logo, se introduz no cercado e se aproxima das galinhas, de orelhas bem abertas para não ser surpreendido - uma vez que ele bem sabe o erro que está cometendo. O medo de ser pego é tanto que até o faz dar meia volta: ele deixa então o terreiro e retorna para a estrada onde fica um momento à espera, mas a necessidade faz o sapo pular e a fome que continua a atormentálo o faz voltar com o objetivo de apanhar as galinhas custe o que custar. Eis então ele novamente dando mãos à sua obra. Ele penetra, pois, na granja pela parte de trás, fazendo tão pouco barulho que ninguém se dá conta de nada, nem as galinhas se movem. Logo aqui estão três, empoleiradas sobre uma viga, sem muito mais tempo de vida. Nosso caçador escala um monte de palha para prender suas vítimas entre os dentes, mas essas últimas, sentindo a palha se mexer, saltam e vão se esconder em um canto. Renart as persegue, encurrala-as uma a uma num cantinho e as estrangula todas três. As duas primeiras lhe permitem matar a fome ali mesmo no local. Quanto à terceira, ele tem a intenção de fazê-la cozida; além do mais, como se sente melhor após ter comido, Renart pretende sair da granja levando-a consigo. Contudo, no momento de passar pela porta, nosso mestre da trapaça, impulsionado também pela sede e vendo o poço no meio do terreiro, se precipita até lá para beber até não suportar mais, mas ele vai ser impedido: na verdade, chegando ao poço, percebe o quanto este é largo e profundo. E é aqui onde a história fica interessante: no poço, havia dois baldes dispostos de tal forma que enquanto um subia o outro descia. Renart, o malfeitor, se apóia sobre a borda, descontente, irritado e, ao mesmo tempo, embaraçado pelo contratempo. Ao olhar para o interior, vê seu próprio reflexo na água e crê que lá no fundo está sua mulher, Hermeline, a quem ama tão 
carinhosamente. Nesse instante, tomado de uma dolorosa surpresa diante daquela visão, ele se pergunta com uma voz bem forte: “O que você está fazendo aí dentro, me diga?". Sua voz ecoa como se ela saísse do poço. Ao escutá-la, ele volta a cabeça e chama novamente. Para sua grande surpresa, o mesmo fenômeno se repete. Ele salta então no balde, sem compreender o que se passa com ele quando começa a descer. O infeliz! Somente quando cai na água é que se dá conta de seu engano.

Lá se vão centenas de instantes de sua vida! Era necessário que o diabo estivesse unido ao seu corpo para que ele pudesse ter chegado ali! Ele se agarrara a uma pedra, mas preferia estar morto e enterrado. Coitado! Ele enfrenta uma rude provação: encharcado até aos ossos, está em melhores condições para uma pesca, mas Renart não está com cabeça para rir e se pergunta como pôde cometer tamanha besteira.

Ora, naquela mesma noite, justamente no melhor momento da história, o lobo Ysengrin, impulsionado pela fome, saía de um campo para procurar o que comer. De muito mau humor, ele se dirige apressado até a habitação dos monges, mas sem encontrar nenhuma ocasião favorável. "Diabo de país!", diz ele a si mesmo, “onde não se encontra nada de bom para colocar na boca e nem mesmo... o que não colocar, absolutamente nada." Sem hesitar, ele corre até uma portinhola e chega correndo em frente a uma casa. Sobre seu caminho, se encontra o poço no fundo do qual Renart, o ruivo, está a se debater. Ysengrin, dividido entre a preocupação e a irritação, vai se inclinar à borda. E lá, se debruçando e olhando com atenção, exatamente como o fez Renart, ele percebe seu próprio reflexo. Crê que é a sua senhora, Hersent, que se instalou lá no fundo com Renart - o que, podem acreditar em mim, não melhora seu humor: "Eis a mim aqui ridularizado, humilhado como um menos que nada pela minha mulher, que esse ruivo seqüestrou para conduzi-la até lá em baixo com ele. Ah! Traidor! Bandido! Abusar assim de sua vizinha e amiga, sem que eu pudesse intervir! Mas se eu o pegasse, eu me vingaria tão bem que eu nunca mais o temeria. [...] Eu te pego com Renart”, grita ele muito forte em direção a seu reflexo. E ele torna a gritar assim que sua voz ecoa no fundo do poço. Ante as lamentações de Ysengrin, Renart nem se mexe; pelo contrário, ele o deixa gritar todas as vezes antes de interpelá-lo:

"Meu Deus, quem é que me chama? Daqui por diante, é aqui que eu tenho minha morada.

- Mas quem é você?

- Sou eu, seu vizinho; antigamente, nós éramos compadres e companheiros. Você gostava mais de mim do que a um irmão. Hoje, chamam-me defunto Renart, que já foi rei da trapaça e do trote. 
- Olhe só quem vai melhor! Mas desde quando você está morto, Renart?

- Há algum tempo. Mas porque se admirar? Assim morremos todos os viventes igualmente. É preciso passar da vida à morte no dia que agradar a Deus. Nosso senhor, que me livrou dessa vida de dor, guarda agora minha alma. E eu te suplico, queridíssimo companheiro, a me perdoar por tê-lo deixado nervoso outro dia.

- Mas é claro! Concordo plenamente. Receba meu perdão, caro companheiro, diante de Deus. Mas sua morte me entristece.

- Por mim, não estou infeliz.

- Você fica feliz?

- Mas é claro.

- E por que então, caro amigo; me diga?

- Porque se meu corpo está no caixão junto com o de Hermeline em minha cova, minha alma está no Paraíso, sentado ao pé de Jesus. Aqui não me falta mais nada, meu amigo; mas é porque eu nunca pequei por orgulho. Logo, enquanto você está no reino da terra, eu estou no do céu. Aqui, só existem campos, bosques, planícies, pastagens. Que abundância! $\mathrm{Ah}$ ! Se você pudesse ver todos os rebanhos, os carneiros, as cabras, os bois, as vacas, as ovelhas, os gaviões, os abutres, os falcões".

Ysengrin jura por São Sylvestre que gostaria de estar em seu lugar.

“Um momento!”, fez Renart, "você não pode entrar aqui desse jeito. O Paraíso é um lugar espiritual que não é dado a todos. Por toda a sua vida, você foi enganador, traidor, mentiroso, trapaceiro. Você não depositou confiança em mim sobre sua mulher. E, contudo, eu tomo Deus Santo como testemunha, [...] eu nunca lhe faltei com respeito. [...] Pelo senhor que me criou, é verdade o que eu lhe digo.

- Eu acredito em você e não te culpo mais, sem receio; mas me ajude a entrar.

- Nem pensar! Nós não queremos nos aborrecer. Você vê essa balança?"

Senhores, escutem o que vou lhes dizer: é de não acreditar nos próprios ouvidos. Com o dedo, Renart mostra o balde para o lobo e chega, por meio de sua grande habilidade, a persuadi-lo de que se tratava de uma balança que serve para pesar as boas e as más ações.

"Por Deus Pai, que é Puro Espírito e Potência, quando o bem pesa o suficiente, aquele que está sentado sobre a plataforma desce até aqui, e todo o mal que ele cometeu fica no alto. Mas ninguém jamais poderá descer sem ter se confessado, eu lhe digo em verdade. Você confessou seus pecados?

- Sim, para uma velha lebre e para um carneiro barbudo, em um espírito de sinceridade e de santificação. Faça-me entrar rápido, companheiro.” 
Renart se pega a olhá-lo: "Então, é necessário que dirija orações sinceras a Deus para que ele lhe perdoe concedendo a remissão de seus pecados. Com essa condição, você poderá ser admitido aqui."

Ysengrin, muito impaciente, vira as costas para o leste e a cabeça para o oeste ${ }^{4}$ e começa a cantar bem forte. Renart, - este não acabou de nos surpreender - se encontrava no fundo do poço, no balde onde ele havia entrado, impulsionado pelo diabo seguramente. Quando Ysengrin lhe diz que terminou sua prece, ele responde que, de sua parte, acabou sua ação de graças, acrescentando: "Você consegue ver o milagre dessas velas que brilham diante de meus olhos, Ysengrin? Deus te concederá a absolvição e generosamente perdoará seus pecados."

Dito isso, Ysengrin faz descer o balde até a borda e salta para dentro de pés juntos. Como ele era mais pesado que Renart, ele desce e este é o diálogo entre eles:

"Por que você está retornando, companheiro?", pergunta Ysengrin. E Renart lhe responde: "Não me olhe assim, eu vou lhe dizer: um vem, o outro se vai. É o funcionamento. Eu subo ao Paraíso, enquanto você desce ao inferno. Enquanto você vai ao diabo, eu escapo dele. Você caiu abaixo do trigésimo sexto e eu me retiro. Agora você fica sabendo. Por Deus Pai e pelo Espírito Santo, em baixo é que ficam os demônios."

Tão logo bota os pés na terra, Renart se vangloria de sua vitória. Agora é hora de Ysengrin ficar em posição desconfortável. Se ele tivesse sido feito prisioneiro pelos infiéis ${ }^{5}$, não estaria pior do que no fundo do poço.

Senhores, saibam que os monges ficaram doentes por comer feijões germinados e muito salgados. E seus empregados, por preguiça, haviam deixado faltar água no convento. Mas eis que o cozinheiro, o que era responsável pelos mantimentos, havia retomado forças suficientes durante a manhã para ir, em bom ritmo, até o poço, juntamente com dois companheiros e um burro. Eles amarram o animal à corda da polia para que este extraia a água, o que ele começa a fazer com ardor, infligido pelos monges. Para sua decepção, o lobo continuava sempre embaixo, no outro balde onde havia escorregado. Se bem que o burro não era dado a esforços, de modo que nem podia avançar, nem recuar, mesmo com as pancadas que recebia. A situação permanece assim até o momento em que um monge, apoiado sobre a borda do poço, se debruça para olhar o fundo. Vendo Ysengrin, ele grita para os outros:

\footnotetext{
${ }^{4}$ Os cristãos oram olhando em direção ao oriente, para o lado de Jerusalém. Ou seja, para o leste. Aqui, Ysengrin apresenta seu traseiro nessa direção! (N. do A.)

${ }^{5}$ Os infiéis são os muçulmanos. (Numerosas cruzadas produziram prisioneiros na batalha de Alep, na Síria, em 1165). (N. do A.)
} 
"Vocês sabem o que estão fazendo, por Deus Pai Todo Poderoso? Vocês estão puxando um lobo do fundo do poço!"

É um pernas para que te quero só. Todos correm, aflitos, até o convento, deixando o burro preso à corda; mas o martírio de Ysengrin ainda não havia terminado. Os irmãos chamam os empregados - e isso não vai ser nem um pouco interessante para o lobo. $\mathrm{O}$ abade toma um grande bastão cheio de nós e o prior um castiçal. Todos os monges, sem exceção, saem do convento portando bastões ou lanças e se dirigem até o poço, decididos a fazer justiça com as próprias mãos. Juntando suas forças às do burro, eles conseguem elevar o balde até a borda. Ysengrin, sabendo bem como seria acolhido, salta tão longe quanto pode. Mas os cães que o perseguem lhe dilaceram a pele fazendo voar tufos de pêlo. Depois os monges o apanham e descem-lhe a pancada. Um deles o atinge direto na altura dos rins. Ele passa um mau quarto de hora, desaparecendo em quatro ocasiões. Finalmente, no limite das forças e da resistência, ele cai estendido e se faz de morto. Nesse momento então chega o prior (que Deus o amaldiçoe!), sua faca na mão, para escalpelar o animal. Ele ia liquidá-lo quando o abade intervém: "Deixe-o! Sua pele não vale à pena; foi feita em pedaços pelas pancadas que demos nela. Ele não fará mais nada e a terra ficará em paz. Entremos. Não nos ocupemos mais com ele." 